\title{
Impact on training programme on Adoption of Improved Dairy Management Practices by the Women Dairy Farmers in Theni District of Tamil Nadu, India
}

\author{
A. Senthilkumar" and S. Murugesan \\ Farmers Training Centre, Tamil Nadu Veterinary and Animal Sciences University, \\ Theni-625531, India \\ *Corresponding author
}

\begin{tabular}{|c|c|}
\hline & A B S T R A C T \\
\hline $\begin{array}{l}\text { Ke y w o r d s } \\
\text { Adoption, Improved } \\
\text { practices, impact, } \\
\text { Training }\end{array}$ & \multirow{3}{*}{$\begin{array}{l}\text { Study was conducted in Theni district of Tamil Nadu to assess the level of adoption of } \\
\text { improved dairy management practices by the women dairy farmers. The data were } \\
\text { collected from eight blocks in Theni District of Tamil Nadu. Randomly } 200 \text { women dairy } \\
\text { farmers as respondents were selected out of } 472 \text { women dairy farmers. Study data were } \\
\text { collected through interview schedule. Women dairy farmers as respondents categorized as } \\
\text { adopters and non adopters. Overall Adoption of improved management practices by } \\
\text { women dairy farmers was } 68.06 \% \text { and overall non Adoption of improved management } \\
\text { practices by women dairy farmers was } 31.94 \% \text {. Adoption of improved management } \\
\text { practices by women dairy farmers plays a key role in increasing production and health } \\
\text { status of dairy animals Thus, it is indicated that the knowledge of dairy farm women } \\
\text { participate was increased due to adoption of improved management practices. }\end{array}$} \\
\hline Article Info & \\
\hline $\begin{array}{l}\text { Accepted: } \\
18 \text { July } 2020 \\
\text { Available Online: } \\
10 \text { August } 2020\end{array}$ & \\
\hline
\end{tabular}

\section{Introduction}

India is predominantly an agrarian economy, with more than $75 \%$ population in villages in depending upon agriculture, animal husbandry and allied activities for their livelihood. Among many livestock enterprises, dairying is the most ancient occupation established in the rural setting of our country. Dairying sector contributes significantly in generating employment opportunities and supplementing the income of small and marginal farmers and landless laborers of rural India, besides providing food security. Dairy farming is considered as an extension of domestic activities like feeding and watering of animal, bringing of fodder from the field, cleaning of animals and sheds, preparation of cow dung cakes etc. Dairying in India is a female dominated enterprise (Fulzele and Meena, 1995). It is established beyond doubt that women always participated in dairy and animal husbandry activities in addition to their daily household chores (Belurkar et al., 2003). About 75 million women as against 1.5 million men engage in dairying in India (Thakur and Chandar, 2006). The importance of training dairy farmwomen 
is progressively realized all over the world. Venugopalan (1992) emphasized that considering women's involvement in a wide range of activities it is evident that their production potentials can be realized only if women get the necessary training, technical knowhow and support. India is the largest producer of milk in the world, but productivity of livestock in India is still dismally low. India possesses enormous bovine wealth, but their per capita production is one of the lowest in the world due to reasons that the farmers do not adopt improved dairy management practices at the desired level.

To enhance the productivity of animals and better management practices are required. Training provides a systematic improvement of knowledge and skills, which in turn helps the trainees to function effectively and efficiently in their given task on completion of the training (Sajeev et al., 2012). Training is viewed as an investment of human resource. This investment has the potentialities in transforming the group of dairy farm women to accomplish the common goal. In fact, training is considered as substitute for change and key to national development. It is a low cost and highly productive method extremely suitable for speedy socio-economic development of the dairy farming community. Need based training programme acts as a catalyst for increasing the motivational level of trainees who in turn try to put their sincere efforts to learn and gain maximum from the training program (Yadav, 2007). Livestock and dairy has been one of the sectors in India where female work force participation has been high. Majority of rural women are involved in animal husbandry, but the nature and extent of their involvement varies widely and is strongly influenced by their economic status, caste and ethnic background. Women are the prime decision makers in dairy production activities such as utilization of milk, care of pregnant animals and calves, brining of fodder and feeding of concentrate. Therefore, the present study was undertaken with following objective:

To assess the adoption of improved dairy management practices by the women dairy farmers after training programme.

\section{Materials and Methods}

Study was conducted in Theni district of Tamil Nadu to assess the level of adoption of improved dairy management practices by the women dairy farmers after training attended. The data were collected from eight blocks in Theni District of Tamil Nadu during the month of June 2019 to August 2019. Totally 472 women dairy farmers were attended training programme on dairy farming conducted by Farmers Training Centre (TANUVAS), Theni during the month of April 2018 to December 2018. Randomly 200 women dairy farmers as respondents were selected out of 472 women dairy farmers attended the training programme. Data for the study were collected through interview schedule. Women dairy farmers as respondents categorized as adopters and non adopters. The interview schedule was divided in following aspects Hygienic management of animals and animal shed, Feeding of green fodders as recommended level, Feeding of mixed green fodders (Leguminous and Non Leguminous), Feeding of dry fodders, Feeding of compound feed in daily ration, Feeding of compound feed in daily ration as per milk production level, Supplementation of mineral mixture in compound feed ration, Feeding of Azolla as a supplementary of green fodder particularly during summer season, Ensuring milking utensils and udder are cleaned before and after each milking, Practicing full hand method of milking, Inseminating the animals when it is in mid 
heat period(standing heat), Practicing pregnancy diagnosis between 60-75 days after artificial insemination, Drying of animals 2 months before parturition, Feeding of Colostrums to newborn calves, Practicing deworming in calf and Ensuring coverage of animal insurance. The respondents data were presented into adopters and non adopters on different aspects of adoption as well as overall adoption of improved dairy management practices.

\section{Results and Discussion}

Adoption of improved management practices by women dairy farmers plays a key role in increasing production and health status of dairy animals. Table 1 indicated the adoption level of different improved dairy management practices by the women dairy farmers of Theni district of Tamil Nadu. From the results, overall Adoption of improved management practices by women dairy farmers was 68.06 per cent and overall non Adoption of improved management practices by women dairy farmers was 31.94 per cent. Thus, it is indicated that the knowledge of dairy farm women participate was increased due to attend the training programme and adoption of improved management practices.

From the results, adoption level of improved dairy management practices like Hygienic Management of animals and animal shed by the women dairy farmers of Theni district was $67.00 \%$. This might be awareness on knowledge about importance of hygienic management of animal shed and animal to reduce the incidence of mastitis problems and increase the quality of milk. Adoption level of improved dairy management practices like Feeding of green fodders as recommended level by the women dairy farmers of Theni district was $60.50 \%$. Thus, it is indicated that farmers learned about the requirement of green fodders based on their body weight.
Adoption level of improved dairy management practices like feeding of mixed green fodders (Leguminous and Non Leguminous) was $73.00 \%$. This might be due to lack of knowledge on leguminous green fodder and importance of leguminous green fodder in daily ration over the non leguminous green fodder in dairy ration to reduce its conception rate of dairy animal.

Adoption level of improved dairy management practices like Feeding of dry fodders by the women dairy farmers of Theni district was $33.50 \%$. The low level of above said adoption might be mainly due to no availability of dry fodder all the seasons of year and price was slightly higher. The role of balanced compound feeding in successful dairy farming is well established. The study revealed that trainees never formulated feed at their farms before training but $65.50 \%$ trained farmers started making compound cattle feed at domestic level regularly after the training. This might be awareness on knowledge about importance of compound feed in feeding management of animal to increase the health status of animal. The study revealed that trainees never feed their animal compound feed in daily ration as per milk production level before training but $60.00 \%$ trained farmers started feeding their animals with compound feed in daily ration as per milk production level regularly after the training. Similarly, trainees never used mineral mixture and no awareness about minerals before training. The percentage of trainees using it on regular basis 81.00 per cent after the training. Increased conception rate and reduction in incidences of health related problems noticed mainly due to regularly using mineral mixture in compound feed ration.

Adoption level of improved dairy management practices like azolla feeding as green fodder supplementary in dairy animal 
by the women dairy farmers of Theni district was $44.00 \%$. This might be due to awareness about knowledge on azolla cultivation method and nutritive value of azolla over the regular green fodder. Feeding of azolla as a green fodder supplements to enhance milk production, reduce the feeding cost particularly oil cake cost. Feeding of azolla particularly very useful during summer and in scarcity. Present finding feeding of azolla in dairy animals agreed with Pannaerker (1988) who reported that feeding of azolla was most economic and efficient feed substitute for dairy animals and increases milk production in animal. Present finding in the value of milk production agreed with Nidhi et al., (2015) who reported that Azolla-fed group showed a significant increase of $11.85 \%$ in milk production. The results of present study near to close agreed with Pillai et al., (2005) who reported that fresh Azolla increased 10-15\% milk production in dairy cattle and saved 20$25 \%$ of commercial regular feeds.

Adoption level of improved dairy management practices like milking utensils and udder are cleaned before and after each milking in dairy farming by the women dairy farmers of Theni district was $71.50 \%$. This might be awareness on knowledge about importance of clean milk production to reduce the incidence of mastitis problems and increase the quality of milk. The study revealed that trainees never milking their animals in full hand method of milking before training. After training, adoption level of improved dairy management practices like practicing full hand method of milking was $56.00 \%$. This might be awareness on knowledge about correct method of milking in dairy animal to reduce the teat problems.

Before training most of the dairy animals were inseminated in early heat period because most of the dairy farmers did not aware of heat symptoms and correct time of inseminating their animals. The study revealed that after attended training, Adoption level of improved dairy management practices like Inseminating the animals when it is in mid heat period-standing heat was $75.50 \%$ that would increase the conception rate and reduce the insemination cost. Similarly, the study revealed that Adoption level of improved dairy management practices like practicing pregnancy diagnosis between 6075 days after service was $70.50 \%$.

This might be due to awareness about knowledge on importance pregnancy verification after inseminating their animals would reduce the anoestrum period. Adoption level of improved dairy management practices like Drying of animals 2 months before parturition was $76.00 \%$ that revealed that awareness about knowledge on importance of Drying of animals 2 months before parturition because calf growth was more rapid in dry period only. Similarly, trainees never used Feeding advance pregnant animal with extra concentrate feed because no income from advanced pregnant animal. But after training attended, Adoption level of improved dairy management practices like Feeding advance pregnant animal with extra concentrate feed was 76.50 that leads better calf growth and increase milk production in succeeding calving.

Adoption level of improved dairy management practices like Feeding of colostrums to newborn calves was $81.00 \%$ that leads better calf growth and increase calf body immunity and also farmers did not aware of importance of feeding of colostrums to newborn calves. Similarly, Adoption level of improved dairy management practices like practicing de-worming in calf was $79.50 \%$ that would increase the health status of calves and also farmers aware of importance of deworming to newborn calves. 
Table.1 Adoption level of different improved management practices

\begin{tabular}{|c|c|c|c|c|c|}
\hline \multirow[t]{2}{*}{ S. No. } & \multirow{2}{*}{$\begin{array}{l}\text { Adoption of different improved } \\
\text { management practices }\end{array}$} & \multicolumn{2}{|c|}{ Adopters } & \multicolumn{2}{|c|}{ Non Adopters } \\
\hline & & $\begin{array}{l}\text { Respondents } \\
\text { Nos. }\end{array}$ & Per cent & $\begin{array}{l}\text { Non-Respondents } \\
\text { Nos. }\end{array}$ & Per cent \\
\hline 1. & $\begin{array}{l}\text { Hygienic Management of animal shed } \\
\text { and animals }\end{array}$ & 134 & 67.00 & 66 & 33.00 \\
\hline 2. & $\begin{array}{l}\text { Feeding of green fodders as } \\
\text { recommended level }\end{array}$ & 121 & 60.50 & 79 & 39.50 \\
\hline 3. & $\begin{array}{l}\text { Feeding of mixed green } \\
\text { fodders(Leguminous and Non } \\
\text { Leguminous) }\end{array}$ & 146 & 73.00 & 54 & 27.00 \\
\hline 4. & Feeding of dry fodders & 67 & 33.50 & 133 & 66.50 \\
\hline 5. & $\begin{array}{l}\text { Feeding of compound feed in daily } \\
\text { ration }\end{array}$ & 131 & 65.50 & 69 & 34.50 \\
\hline 6. & $\begin{array}{l}\text { Feeding of compound feed in daily } \\
\text { ration as per milk production level }\end{array}$ & 120 & 60.00 & 80 & 40.00 \\
\hline 7. & $\begin{array}{l}\text { Supplementation of miner mixture in } \\
\text { compound feed ration }\end{array}$ & 162 & 81.00 & 38 & 19.00 \\
\hline 8. & $\begin{array}{l}\text { Feeding of Azolla as a supplementary } \\
\text { of green fodder particularly during } \\
\text { summer season }\end{array}$ & 88 & 44.00 & 112 & 56.00 \\
\hline 9. & $\begin{array}{l}\text { Ensuring milking utensils and udder } \\
\text { are cleaned before and after each } \\
\text { milking }\end{array}$ & 143 & 71.50 & 57 & 28.50 \\
\hline 10. & Practicing full hand method of milking & 112 & 56.00 & 88 & 44.00 \\
\hline 11. & $\begin{array}{l}\text { Inseminating the animals when it is in } \\
\text { mid heat period-standing heat }\end{array}$ & 151 & 75.50 & 49 & 24.50 \\
\hline 12 & $\begin{array}{l}\text { Practicing pregnancy diagnosis } \\
\text { between 60-75 days after artificial } \\
\text { insemination }\end{array}$ & 141 & 70.50 & 59 & 29.50 \\
\hline 13 & $\begin{array}{c}\text { Drying of animals } 2 \text { months before } \\
\text { parturition }\end{array}$ & 152 & 76.00 & 48 & 24.00 \\
\hline 14 & $\begin{array}{l}\text { Feeding advance pregnant animal with } \\
\text { extra concentrate }\end{array}$ & 153 & 76.50 & 47 & 23.50 \\
\hline 15 & $\begin{array}{c}\text { Feeding of colostrum to newborn } \\
\text { calves }\end{array}$ & 162 & 81.00 & 38 & 19.00 \\
\hline 16 & Practicing de-worming in calf & 159 & 79.50 & 41 & 20.50 \\
\hline 17 & Coverage of animal Insurance & 172 & 86.00 & 28 & 14.00 \\
\hline & Overall Adoption & 2314 & 68.06 & 1086 & 31.94 \\
\hline
\end{tabular}

Adoption level of improved dairy management practices like insurance of dairy animals by the women dairy farmers of Theni district was $86.00 \%$. This might be due to awareness on importance of insurance their animal to reduce the risk of loss of animals and increase the continuing the farm activity 
It can be concluded from the above findings that $68.06 \%$ of respondents were adopted about improved dairy management practices. All improved dairy management practices, the level of adoption of was more than $50.00 \%$ except for feeding of dry fodder and Azolla supplementary feeding. Therefore, recommendation on the basis of findings and observations those efforts should be made to encourage the women dairy farmers about the adoption of feeding of dry fodder and Azolla supplementary feeding. More efforts should be taken by the Government as well as extension functionary and policy makers for organizing such type need based training programme for uplifting the dairy farm women and indirectly the dairy industry. Training is beneficial in reducing the constraints intensity and helpful in better dairy farming. Tripp et al., 2005 confirmed the importance of training in enhancing farmers skills in farming works.

\section{References}

Fulzele, R.M. and Meena, B.L. (1995). Training needs of dairy tribal women. Indian. J. Dairy Sci., 48: 551-553.

Belurkar, G.M., Wakle, P.K. and Gholve, M.A. (2003). A study on decision making pattern and participation of rural women in animal husbandry and dairying enterprise. Maha. J. Ext. Edu., 22(2): 81-85.

Thakur, D. and Chandar, M. (2006). Gender based differential access to information among Livestock owners and it's impact on house hold milk production in Kangra district of Himachal Pradesh. Indian. J. Dairy. Sci., 59(6): 401-404.

Venugopalan, M. (1992). Training need of rural women in home science, Agricultural and A.H. activities. Ext. Rev., 4: 27-29.

Sajeev, M.V., Singha, A.K. and Venkatasubramanian, V. (2012). Training Needs of Farmers and Rural Youth: An Analysis of Manipur State. India. J. Agri. Sci., 3(2): 103-112.

Yadav, B., Goel, R., Dahiya, R. and Kundu, P. (2007). Training need of rural women in home science, agricultural and animal husbandry activities. J. Dairying, Foods \& H. S., 26: 137-140.

Pannaerker, S. 1988. Azolla as a livestock and poultry feed. Livestock Advisor, 13: 2226.

Nidhi, R., Kumari,k., Singh,f and Gilhare,V.R.,2015. Effect of azollasupplemented feeding on milk production of cattle and production performance of broilers. Applied Biological Research 17(2): 214-218.

Pillai, P.K., Premalatha, S. and Rajamony, S. 2005.Azolla: A sustainable feed for livestock. LEISAIndia, 21(3): 26-27. Singh, P.K. and Subudhi, B.P.R. 1978

Tripp R., Wijeratne M. and Hiroshini V., 2005. What Should We Expect from Farmer Field Schools? A Sri Lanka Case Study. World Development, 33(10): 1705-1720.

\section{How to cite this article:}

Senthilkumar, A. and Murugesan, S. 2020. Impact on Training Programme on Adoption of Improved Dairy Management Practices by the Women Dairy Farmers in Theni District of Tamil Nadu, India. Int.J.Curr.Microbiol.App.Sci. 9(08): 1844-1849.

doi: https://doi.org/10.20546/ijcmas.2020.908.211 